\title{
Influence of ultraviolet radiation on the colony formation of Fomes annosus (Fr.) Cooke diaspores suspended in water
}

\author{
Tauno Kallio
}

\begin{abstract}
Department of Plant Pathology, University of Helsinki Viikki, 00710 Helsinki 71, Finland
Abstract. - F. annosus diaspores suspended in water were exposed to ultraviolet radiation, wavelength $365 \mathrm{~nm}$. Colony formation of the diaspores was reduced in exponential response to the ultraviolet radiation. The colony formation of basidiospores declined more than that of asexual diaspores.
\end{abstract}

\section{Introduction}

The wavelength, dose and dose-rate of radiation affect fungal growth and sporulation (LEAGH 1962a, b, 1963). The effect of radiation on fungi may be a result of the substances it induces in the fungi (LEAGH 1965) or the mutations it produces (NoRman 1951, CASTRO F. et al. 1971). The same part of the spectrum has been found to affect both sexual and asexual reproduction (LeAch \& Trione 1966).

Irradiation of Glomerella cingulata Stoneman spores with ultraviolet wavelengths below $313 \mathrm{~nm}$ showed that an exposure time of $5 \mathrm{sec}$. inhibited the germination, and an exposure time of $15 \mathrm{sec}$. killed all the spores. Ultraviolet irradiation was also found to inhibit the mycelial growth of G. cingulata (STEVENS 1928). Radiation of a wavelength of $265 \mathrm{~nm}$ has been seen to inhibit the germination of Rhizopus suinus Niels. conidia (Dimond \& Duggar 1940). Inactivation of micro- and macroconidia of Neurospora crassa Shear \& Dodge by ultraviolet radiation has also been demostrated. The effect was most intense in the wavelength range of $240-280$ $\mathrm{nm}$. The inactivating effect on microconidia exceeded that on macroconidia (Norman 1951). The conidia of Pyricularia oryzae Cav. died in $180 \mathrm{sec}$. under ultraviolet radiation (Manibhushanrao \& Suryanarayanan 1971). Information about the influence of visible and near visible radiation on wood-decaying fungi is relatively scant. Light has been found to stimulate the sporulation of Trichoderma viride Pers. ex Fries (Gutter 1957). Violet and blue light were very effective in stimulating the sporulation of Trichoderma lignorum (Tode) Harz. (Mrller \& ReID 1961). Infrared radiation of long duration is most potent in retarding the mycelial growth of Fomes annosus, whereas infrared radiation lasting less than $10 \mathrm{~min}$. stimulates mycelial growith. Solar, ultraviolet and X-ravs radiation, if of long duration, inhibits the mycelial growth of this fungus (Negruckij 1962). In the laboratory, the fungus has produced conidia both in light and darkness (RIshвeth 1951).

As day advances and the sun rises higher, the short-wave portion of the spectrum extends into a range of even shorter wavelength radiations, while in the long-wave the radiation is of approximately the same wavelength all day long (SüRING et al. 1934, LuNELUND 1945). Clouds in front of the sun considerably reduce the amount of ultraviolet radiation reaching the ground. Even a thin shroud of cloud reduces the ultraviolet irradiance by 


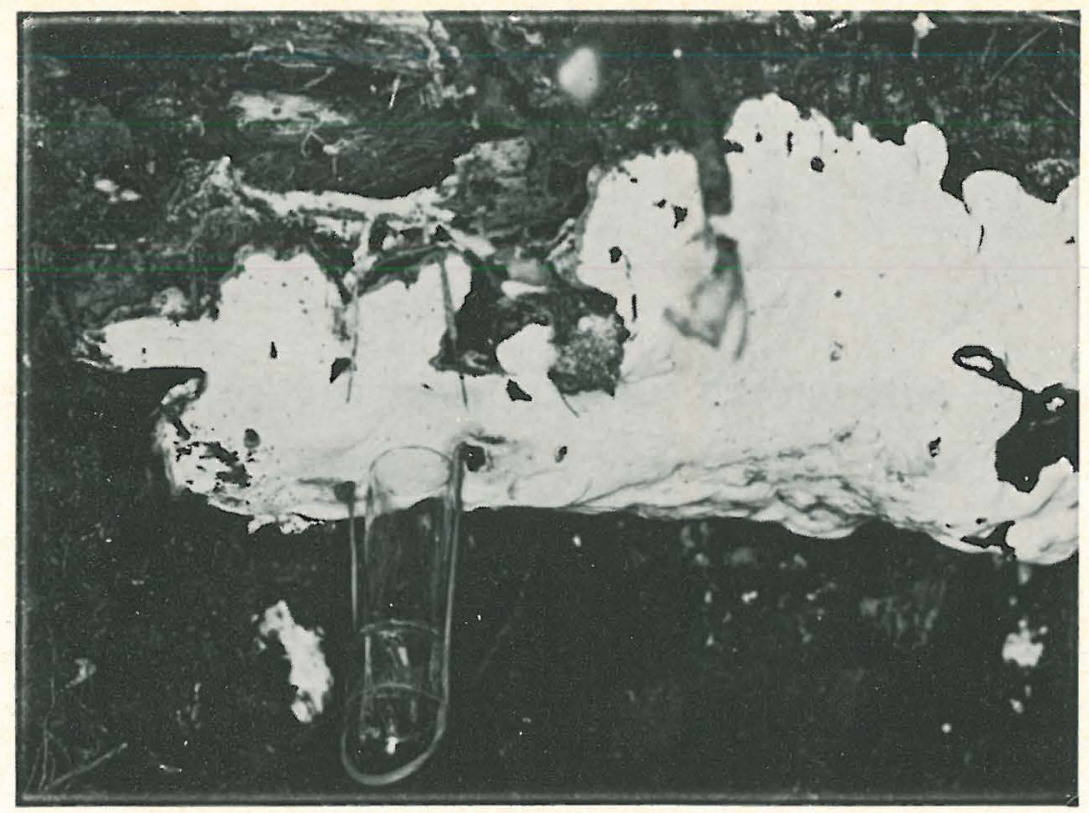

Fig. 1. Collection of basidiospores.

20 per cent (Lunelund 1945). The increase of short-wave radiation in the middle of the day may contribute towards the sharp fall in the deposition of airborne $F$. annosus diaspores around noon (Kallio 1970). The purpose of the present study was to investigate the effect of ultraviolet radiation of 365 $\mathrm{nm}$ on the colony formation of both sexual and asexual diaspores of $F$. annosus.

\section{Material and methods}

1. Effect of ultraviolet radiation on colony formation by asexual diaspores

The $F$. annosus isolate used in the study was derived from a spruce tree (Picea abies (L.) Karst.) in Helsinki. Isolations were grown on $9 \mathrm{~cm}$ Petri dishes with $25 \mathrm{ml}$ malt agar. After 10-15 days on thi's substrate, the agar was transferred to a flask containing $1000 \mathrm{ml}$ water. The agar remaining unbroken in the flask rotated gently for $10 \mathrm{~min}$. Ten $\mathrm{ml}$ suspension was then pipetted from this flask into $50 \mathrm{ml}$ water. The suspension was kept in glass bottles under ultraviolet radiation, $50 \mathrm{~cm}$ from the source of light (lamp Airam HgMu $125 \mathrm{~W}$ ). Thermal radiation of the bottles was inhibited by means of a water filter. According to the measurements of $\mathrm{Oy}$
Airam Ab, Lamp Manufacturers (Research Engineer M. Saarinen), the water filter and the bottles used allowed 90-92 per cent of the emitted $365 \mathrm{~nm}$ radiation to pass through. Having passed through the water filter and the top surface of the bottle the dose-rate was $113-115 \mu \mathrm{W} / \mathrm{cm}^{2}$. The irradiation took place in a dark room with an air temperature of approx. $26^{\circ} \mathrm{C}$. The exposure times were of 2,4 and 6 hours duration. There was one control bottle per exposure time. The diaspores were suspended in the water for the prescribed time, but their bottles were kept in darkness and were not exposed. On completion of irradiation, 0.1 $\mathrm{ml}$ suspension was cultured on malt agar in a Petri dish, diameter $14 \mathrm{~cm}$, the suspension being spread as evenly as possible over the agar surface. The number of $F$. annosus colonies was counted from the substrate 10 days later. The results were calculated as mean values of four parallel cultures. The experiment was repeated 20 times.

\section{Effect of ultraviolet radiation on basidio- spores}

Basidiospores were caught during the period from August 2 to September 10, 1971, from sporophores on the root undersurfaces of old stumps in a hundred year old, $F$. 


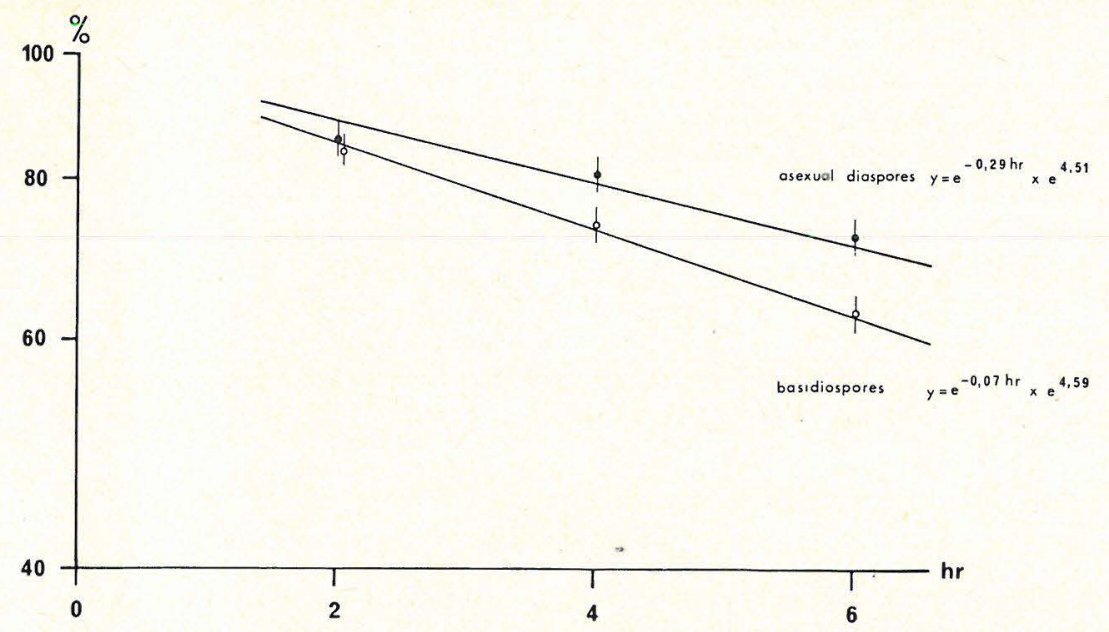

Fig. 2. Influence of ultraviolet radiation on colony formation by diaspores. Triple standard deviation is shown on either side of the percentages.

annosus contaminated spruce stand in Helsinki. With the utmost care, a little earth was removed from beneath the sporophores so that it was possible to attach a test tube against the white, active-looking sporophores (Fig. 1). The length of the tubes used was $60 \mathrm{~mm}$, the diameter $12.7-13.9 \mathrm{~mm}$, and the cross-section area $127-152 \mathrm{~mm}^{2}$. Attached by an elastic band, the tube remained in position, with its opening against the sporophore surface, for 18 hours (from 14.00 to 08.00). The sporophore had been exposed $2-4$ hours before the tube was fastened to its surface. The tube was never fastened twice to the same point on the sporophore surface, and a tube was applied to the same sporophore on a maximum of two days. The hole dug in the ground to expose the sporophore was covered by plastic film during this time. Hence the active surface covered by the tube was fresh every time and was able to continue undisturbed spore production. The production during the period of the study ranged from 48,000 to 419,000 spores/ $\mathrm{cm}^{2} / \mathrm{hr}$. After the observations were completed, the sporophore was removed and studied in the laboratory. Not once were conidiophores seen on its surface.

Basidiospores were irradiated in the same way as asexual diaspores. $3 \mathrm{ml}$ water was added to the test tube that had been covering the sporophore. $1 \mathrm{ml}$ of this suspension was added to $1000 \mathrm{ml}$ water. $10 \mathrm{ml}$ of this suspen- sion again was added to $50 \mathrm{ml}$ water, and the resulting suspension was exposed to ultraviolet radiation in the same way as the suspension of asexual diaspores. Cultures were carried out and results calculated in the same way as for asexual diaspores.

\section{Results and discussion}

The results are shown in the form of graphs in Fig. 2. The effect of ultraviolet radiation on the colony formation by $F$. annosus diaspores can be seen from the exponential response. A similar result, by a closely corresponding method, was obtained with the conidia of Pyricularia oryzae Cav. (Manibhushanrao \& Suryanarayanan 1971) and Neurospora crassa Shear \& Dodge (NorMAN 1951).

The effect of ultraviolet radiation on the $F$. annosus diaspore colony formation, according to the $t$ test, was highly significant for all three exposure times (2, 4 and 6 hours). The differences between 2 and 4 , and 4 and 6 hours were also highly significant. After an exposure time of 2 hours the difference in colony formation between asexual and sexual diaspores was significant with a probability of 2 per cent, and after exposure times of 4 and 6 hours with a probability of 0.1 per cent. The difference may be due to the larger number of nuclei in the conidia 
(cf. Roll-Hansen 1940, Norman 1951), or other structural differences between sexual and asexual diaspores (Dimond \& DUGgar 1941, Sussman \& Halvorson 1966). The diaspore density in the suspension subjected to irradiation varied in the present study, averaging 54/0.1 ml among the asexual diaspores able to form colonies, calculated from the control suspension, and the basidiospore density, accordingly, 29/0.1 ml. This may also have contributed to a smaller fall in the colony formation of asexual diaspores than in that of basidiospores (cf. NoRman 1951). According to regression analysis, the time of ultraviolet radiation explained 18 per cent of the variation in the colony formation of asexual diaspores, while for the sexual diaspores the percentage was 56 . This finding would also suggest that some factor other than ultraviolet radiation exerted a greater effect among the asexual than the sexual diaspores. This view is supported by the result of the two-factor variance analysis.

\section{REFERENCES}

Castro F. J., Zentmyer, G. A. \& Belser, W. L., JR. 1971: Induction of auxotrophic mutants in Phytophthora by ultraviolet light. - Phytopathol. 61: 283-289.

Dimond, A. E. \& DugGar, B. M. 1940: Effects of ultraviolet radiation on the germination and morphology of spores of Rhizopus suinus. - J. Cell. Physiol. 16: 55-61.

- 1941: Some lethal effects of ultra-violet radiation on fungus spores. - Proc. nat. Acad. Sci. U.S.A. 27: 459-468.

Gutter, Y. 1957: Effect of light on sporulation of Trichoderma viride Pers. ex Fries. Bull. Res. Counc. of Israel, Vol. 5D: 273 $-286$.

KALLIO, T. 1970: Aerial distribution of the rootrot fungus Fomes annosus (Fr.) Cooke in Finland. - Acta Forestalia Fennica 107: $1-55$.

LEACH, G. M. 1962a: Sporulation of diverse species of fungi under near-ultraviolet radiation. Canad. J. Bot. 40: 151-161.

- 1962b: The quantitative and qualitative relationship of ultraviolet and visible radiation to the induction of reproduction in Ascochyta pisi. - Canad. J. Bot. 40: 1577 -1602 .

- 1963: The qualitative and quantitative relationship of monochromatic radiation to sexual and asexual reproduction of Pleospora herbarum. - Mycologia 55: 151163.

- 1965: Ultraviolet-absorbing substances associated with light induced sporulation in fungi. - Canad. J. Bot. 43: 185-200.

- \& Trione, E. J. 1966: Action spectara for light-induced sporulation of the fungi Pleospora herbarum and Alternaria dauci. Photochem. Photobiol. 5: 621-630.

Lunelund, H. 1945: Den ultravioletta solstrålningen i Finland. - Nordenskiöld-samfundets tidskr., nr 5: 1-23.

Manibhushanrao, $\mathrm{K}$. \& Suryanarayanan, $\mathrm{S}$. 1971: Isolation of an inositol-less mutant of
Pyricularia oryzae Cav. by ultraviolet irradiation. - Phytopathol. Z. 72: 67-75.

Miller, J. J. \& Reid, J. 1961: Stimulation by light of sporulation in Trichoderma lignorum (Tode) Harz. - Canad. J. Bot. 39: $259-262$.

Negruakij, S.F. 1962: (The effect of different kinds of radiation energy on the growth of Fomes annosus.). Nauc. Dokl. Vyss. Skoly (Biol. Nauki), Moskva 1962 (3) : 97-100.

Norman, A. 1951: Inactivation of Neurospora conidia by ultraviolet radiation. - Exper. Cell Res. 2: 454-473.

Rishbeth, J. 1951: Observations on the biology of Fomes annosus, with particular reference to East Anglian pine plantations. II. Spore production, stump infection, and saprophytic activity in stumps. - Ann. Bot. N.S. 15 (57): $1-21$.

Roll-Hansen, F. 1940: Undersøkelser over Polyporus annosus Fr., saerlig med henblikk på dens forekomst i det sønnafjelske Norge. Summary: A. An investigation of the possibility of ascertaining different races of Polyporus annosus connected with different hosts or localities in Norway south of the Dovrefjell. B. The most important results of the investigation of Polyporus annosus otherwise. - Meddel. fra Det Norske Skogforsøksvesen $\mathrm{nr} .24$ (Bind 7): 1-100.

Stevens, F. L. 1928: Effects of ultra-violet radiation on various fungi. - Bot. Gaz: 86: 210 -225 .

Süring, R., Kühl, W. \& AlbreGht, F. 1934: Ergebnisse der Sonnenfinsternisexpedition des Meteorologischen Observatoriums Potsdam nach Lappland im Juni und Juli 1927. - Veröff. des Preuss. Met. Instituts Nr. 403, Abh. Bd. 10, Nr. 4.

Sussman, A. S. \& Halvorson, H. O. 1966: Spores: their dormancy and germination. - $354 \mathrm{pp}$. Harper \& Row, Publishers. New York and London. 